We thank Bruce A. Sidwell for technical assistance.

J. W. Mrtchell

N. Mandava

J. R. Plimmer

J. F. WORLEY

M. E. Drowne

Crops Research Division,

Agricultural Research Service,

US Department of Agriculture,

Beltsville, Maryland.

Received July 3, 1969

${ }^{1}$ Mitchell, J. W., and Livingston, G. A., Methods of Studying Plant Hormones and Growth-Regulating Substances, Agriculture Handbook No. 336 (CS Government Printing Office, Washington, 1968).

${ }^{2}$ Wiemann, J., Thuan, S. 'T., and Conia, J. M., Bull. Soc. Chim. France, 908 (1957).

${ }^{3}$ Organic Synthesis (edit. by Gilman, H., and Blatt, A. H.), 1, 199 (Wiley, New York, 1967).

- Organic Synthesis (edit. by Gilman, H., and Blatt, A. H.), 1, 345 (Wiley, New York 1967).

\section{Effect of Ethylene on Tuber Initiation in Solanum tuberosum L.}

RENEWED interest in the physiological effects of ethylene has resulted from the suggestion that this hydrocarbon is a plant growth regulator ${ }^{1}$. Ethylene is a natural plant product which effects several important growth processes, notably the inhibition of longitudinal expansion and the promotion of lateral expansion of cells. Tuber initiation in Solanum species involves a lateral expansion of cells in the sub-apical region of the stolon ${ }^{2}$, so we have investigated the extent to which tuberization can be influenced by ethylene.

Sprouts of Solanum tuberosum ('Arran Pilot' variety), grown in the light until about 5-7 $\mathrm{cm}$ long and bearing several stolons, were excised from tubers together with a $25 \mathrm{~cm}^{3}$ portion of mother tissue and planted in boxes containing 'Perlite' moistened with nutrient solution. The light-tight boxes were placed in a growth room at $12^{\circ} \mathrm{C}$ and ethylene at a concentration of 50 v.p.m. in humidified air was passed through the boxes at a rate of $250 \mathrm{ml}$. min $^{-1}$. The concentration was checked daily by gas-solid chromatography on an alumina column ${ }^{3}$. Control tissues were kept in identical conditions in a stream of air containing no detectable ethylene. There were nine sprouts per replicate and three replicates per treatment. After 14 days the sprouts were harvested and inspected (Fig. 1).

In all cases, treatment with ethylene led to inhibition of the extension growth of both the sprout and the stolon, loss of the positive geotropic response of the shoot and inhibition of root development. Most striking of the growth responses to treatment with ethylene was the swelling of all rapidly expanding regions--sub-apical regions of stolons, stem and axillary buds. The sub-apical swellings on the stolons of the treated sprouts were similar in morphology and anatomy to normal tubers at a similar stage of development. In contrast to tuber initials, however, sections of the swellings induced by ethylene failed to show a colour reaction with iodine solution, indicating that little or no starch was present. There were less than ten tubers on the stolons of the control sprouts whereas every stolon of the treated sprouts had swollen.

Preliminary experiments on sprouts using 'Ethrel' (2chloroethyl phosphonic acid), which releases ethylene in plant tissues, indicate that this compound causes effects similar to those of gaseous ethylene. Moreover, direct application to the stolon promotes swellings of the subapical region within a week at $18^{\circ} \mathrm{C}$. The swellings obtained with 'Ethrel' treatment do not contain starch.
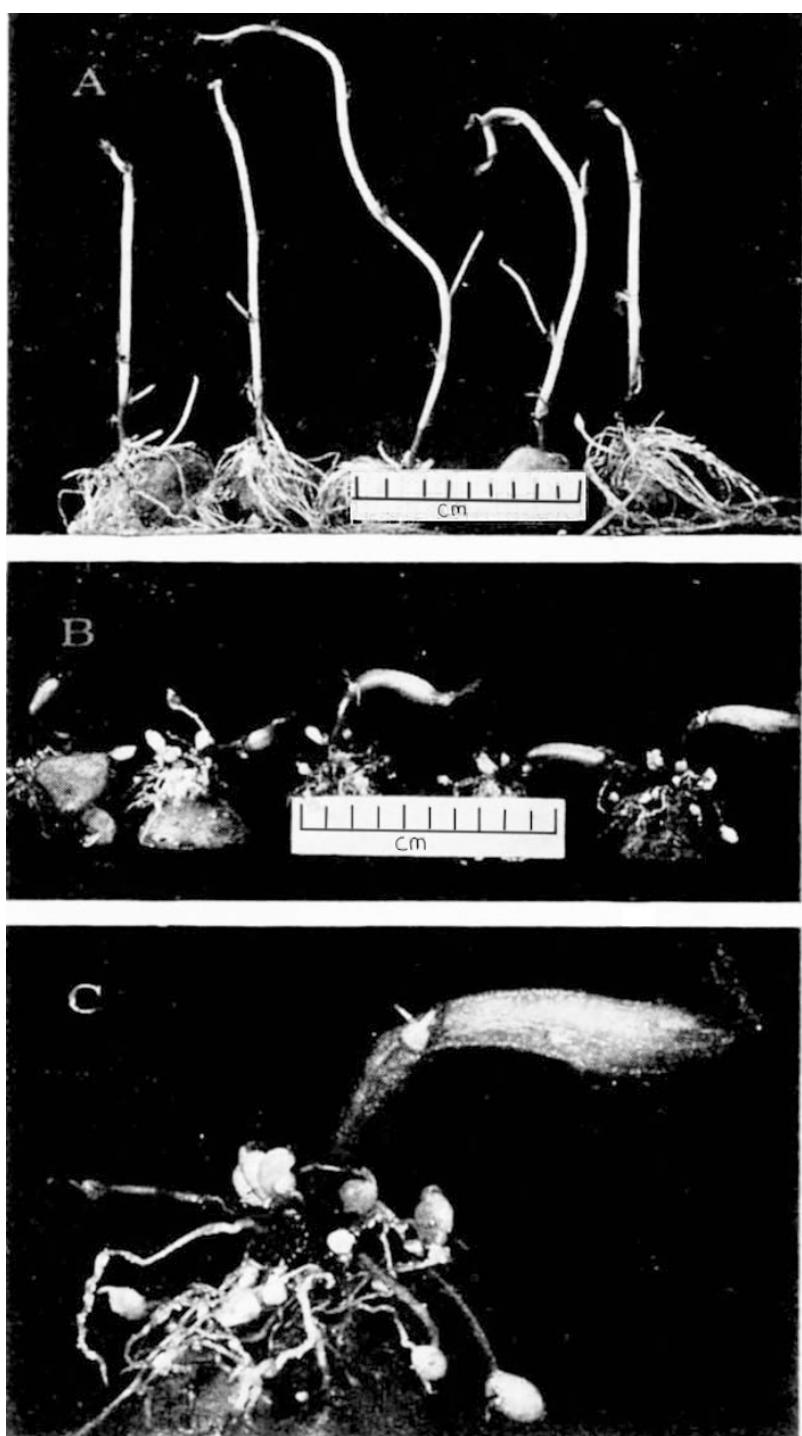

Fig. 1. A, Untreated control sprouts. The curvature of some of the shoots was due to contact with the planting box lids. $B$, Ethylene reated sprouts. $C$, Close-up of a typical ethylene treated sprout showing swollen stem, axillary buds and stolon tips.

These findings open up the interesting possibility that ethylene may play a part in the early stages of tuber initiation, and that starch deposition may occur at a separate stage of development.

We thank Professor M. B. Wilkins for his interest and encouragement, and A. H. Marks and Co., Ltd, for gifts of 'Ethrel'.

A. H. Catchpole

J. HILtaIAN

Department of Physiclogy and

Environmental Studies,

University of Nottingham,

School of Agriculture,

Sutton Bonington,

Loughborough,

Leicestershire.

Received July 25, 1969.

Osborne, D. I., in Plant Grouth Regulators, Soc. Chem. Ind. Monog. No, 31 $236(1.968)$

Booth, A., in The Giouth of the Potato, Proc. Tenth Easter School Agric. Sei., Univ, of Tottingham, 99 (1963)

${ }^{3}$ Smith, K. A., and Scott Russell, R., Nature, 222, 769 (1969). 